\title{
Production, purification and biochemical characterization of an exo-polygalacturonase from Aspergillus niger MTCC 478 suitable for clarification of orange juice
}

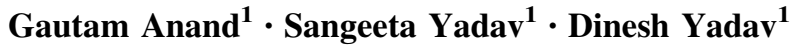

Received: 3 December 2016/Accepted: 2 February 2017/Published online: 31 May 2017

(C) Springer-Verlag Berlin Heidelberg 2017

\begin{abstract}
Polygalacturonases (PG) represent an important member of pectinases group of enzymes with immense industrial applications. A fungal strain Aspergillus niger MTCC478 was used for the production of polygalacturonase both under submerged and solid-state fermentation condition. Further its production was optimized under solid-state fermentation condition with media comprising of wheat bran and tea extract. Purification of an exo-PG was achieved by acetone precipitation (60-90\%) and CMcellulose column chromatography revealing 15.28 -fold purification with a specific activity of $33.47 \mathrm{U} / \mathrm{mg}$ protein and $1.2 \%$ yield. A relative molecular mass of purified PG was approximately $124.0 \mathrm{kDa}$. The $\mathrm{pH}$ and temperature optimum was found to be 4 and $50{ }^{\circ} \mathrm{C}$, respectively. The $k_{\text {cat }}$ and $K_{\mathrm{m}}$ value for degradation of PGA by the purified enzyme was found to be $194 \mathrm{~s}^{-1}$ and $2.3 \mathrm{mg} / \mathrm{mL}$, respectively. $\mathrm{Cu}^{2+}$ was found to enhance the PG activity while $\mathrm{Ag}^{+}$completely inhibited the enzyme activity. The application of the purified PG in orange juice clarification was elucidated.
\end{abstract}

Keywords Polygalacturonase - Aspergillus niger MTCC478 · Exo-PG · Fruit juice clarification · Solid-state fermentation

Dinesh Yadav

dinesh_yad@rediffmail.com

1 Department of Biotechnology, D.D.U Gorakhpur University, Gorakhpur, UP 273 009, India

\section{Introduction}

Pectin, an acidic polysaccharide whose basic structural repeats are $\alpha$-1,4-linked-D-galacturonic acid, is widely found in the middle lamella and primary cell wall of plants. As an important renewable resource, pectin has great potential applications in the biomedical, food, agricultural, and other industries (Mohnen 2008). The degradation of pectin is mainly facilitated by pectinases group of enzymes, including pectin methyl esterases (PME, E.C. 3.1.1.11), pectin lyases (PL, E.C. 4.2.2.10), exopolygalacturonase (exo-PG, E.C. 3.2.1.67), and endopolygalacturonase (endo-PG, E.C. 3.2.2.15) (Yadav et al. 2009).

Polygalacturonases are pectin-degrading proteins that catalyze hydrolysis of $\alpha-1,4$-glycosidic linkages in pectate or other galacturonans at the end, exo-PG (EC 3.2.1.67) or randomly in the middle, endo-PG (EC 3.2.1.15) of polymeric chains. Polygalacturonases (PGs) are produced by various organisms, such as plants (Bird et al. 1988; Hadfield and Benett 1998), bacteria (Jayani et al. 2010; Tariq and Latif 2012; Chen et al. 2014) and fungi (Martins et al. 2013; Ortega et al. 2014; Cheng et al. 2016).

In general, both submerged state fermentation (SmF) and solid-state fermentation (SSF) have been successfully used in pectinases production from different microbial strains (Castilho et al. 2000; Silva et al. 2002; Pedrolli and Carmona 2009; Dinu et al. 2007). The solid-state fermentation is preferred over submerged fermentation based on the fact that it uses various agro-industrial by-products such as soy, pulps of apple, sugar beet and coffee, peels of lemon, oranges and tomato, pomace of apple and citrus fruits, sugarcane bagasse, wheat bran, etc., making the entire process cost effective (Castilho et al. 2000; Yadav and Shastri 2007; Lara-Marquez et al. 2011; Yadav et al. 2014). 
Enzymes produced from the fungi Aspergillus, Rhizopus and Penicillium are generally regarded as safe (GRAS) and produce extracellular enzymes which can be easily recovered (Mrudula and Anitharaj 2011). In vegetable and fruit juice industry, juices with high clarity and low viscosity have high commercial values. Fruit generally contains pectin and other polysaccharides leading to fouling and colloid formation and substantially influences the commercial value of juices. Acidophilic pectinases can degrade pectin resulting in viscosity reduction and cluster formation, which facilitates separation through centrifugation or filtration. As a result, the juice attains higher clarity and flavor.

Microbial polygalacturonases have been shown to play role in viscosity reduction and clarification of juice (Kashyap et al. 2001; Kant et al. 2013; Barman et al. 2015; Amin et al. 2017). Acidophilic PGs with optimum $\mathrm{pH}$ close to $\mathrm{pH}$ of fruit juices are preferably utilized for juice preparation and clarification. Commercial pectinases from Aspergillus niger (Perrone et al. 2006) and Bacillus subtilis (Takao et al. 2000) have been predominantly used as enhancers of juice clarity, color and yield (Oszmianski et al. 2009).

The production, purification and biochemical characterization of polygalacturonase from a fungal strain Aspergillus niger MTCC 478 and its application in fruit juice clarification is reported in the present manuscript.

\section{Materials and methods}

\section{Chemicals}

Polygalacturonic acid (PGA) and CM-cellulose were purchased from Sigma Chemical Company (St. Louis, MO, USA). Rest of the chemicals were procured either from Merck (Navi Mumbai, India) or S.D. Fine (Mumbai, India) and were used without further purification.

\section{Organism and growth condition}

The fungal strain Aspergillus niger MTCC 478 was procured from Microbial Type Culture Collection and Gene Bank, Institute of Microbial Technology, Chandigarh (India) and screened for pectinase production by plate assay method (Molina et al. 2001). The culture was maintained by cultivation on Czapek-Dox agar slants at $26^{\circ} \mathrm{C}$. Based on prominent halo zone formation, the culture was further screened for PG production both under submerged and solid-state fermentation conditions. Submerged fermentation media (M1) comprised $\left(\mathrm{NH}_{4}\right)_{2} \mathrm{SO}_{4} 2 \mathrm{~g} / \mathrm{L}, \mathrm{K}_{2} \mathrm{HPO}_{4}$ $2 \mathrm{~g} / \mathrm{L}, \mathrm{KH}_{2} \mathrm{PO}_{4} 2 \mathrm{~g} / \mathrm{L}$, Yeast extract $3 \mathrm{~g} / \mathrm{L}$, pectin $5 \mathrm{~g} / \mathrm{L}$, $\mathrm{pH}$ 7.0. The inoculum (4\% v/v) was transferred to $25 \mathrm{~mL}$ production media in 250-mL Erlenmeyer flask. Cultures were kept in an incubator shaker at $26^{\circ} \mathrm{C}$ and $150 \mathrm{rpm}$.
Two different media were used for solid-state fermentation. One of the production mediums (M2) consisted of wheat bran $5.0 \mathrm{~g}$ and $5 \mathrm{~mL}$ of salt solution. The other medium (M3) consisted of wheat bran $4.5 \mathrm{~g}$, tea extract $0.5 \mathrm{~g}$ and $5 \mathrm{~mL}$ salt solution. The composition of salt solution was ( $4 \mathrm{~g} / \mathrm{L}$ each of $\mathrm{K}_{2} \mathrm{HPO}_{4}, \mathrm{KH}_{2} \mathrm{PO}_{4}$, and $\mathrm{NH}_{4} \mathrm{SO}_{4}$ ) and final moisture content was kept $50 \%$. The inoculum $(10 \% \mathrm{v} / \mathrm{w})$ was transferred to the production media in $250-\mathrm{mL}$ Erlenmeyer flask. Flasks were incubated at $26{ }^{\circ} \mathrm{C}$ and cultures were allowed to grow under stationary condition.

\section{Production of polygalacturonase}

The fungal strain Aspergillus niger MTCC 478 was grown in ten 250-mL Erlenmeyer flasks containing M3 media. The media was inoculated with $1 \mathrm{~mL}$ of spore suspension $\left(5 \times 10^{6}\right.$ spores $\left./ \mathrm{mL}\right)$ in each flask and the flasks were kept at $26{ }^{\circ} \mathrm{C}$ in a biological oxygen demand incubator (BOD). On the day of maximum enzyme production, $15 \mathrm{~mL}$ of cold distilled water was added in each flask and mixed properly with the help of glass rod. All the cultures were pooled and filtered with four layers of cheese cloth; the filtrate was centrifuged at $10,000 \mathrm{rpm}$ for $20 \mathrm{~min}$ at $4{ }^{\circ} \mathrm{C}$. The pellet was discarded and supernatant was used as crude enzyme sources.

\section{Polygalacturonase assay and protein estimation}

Enzyme activity of PG was assayed by determining the liberated reducing-end products by standard method (Miller 1959). The reaction solution (2 mL) consisted of $0.5 \mathrm{~mL}$ of $1 \%$ PGA, $1.4 \mathrm{~mL}$ of $100 \mathrm{mM}$ citrate-phosphate buffer (pH 4.0) and $0.1 \mathrm{~mL}$ of enzyme solution. It was incubated for $20 \mathrm{~min}$ at $37{ }^{\circ} \mathrm{C}$ in a water bath. Three $\mathrm{mL}$ of dinitrosalicylic acid (DNSA) reagent was added and volume was made $6 \mathrm{~mL}$ by addition of $1 \mathrm{~mL}$ of distilled water. The solution was boiled for $10 \mathrm{~min}$ in a water bath, cooled and absorbance was read at $575 \mathrm{~nm}$ in a colorimeter. A control was simultaneously prepared taking thermally denatured enzyme. The concentration of the product (galacturonic acid) was compared to a galacturonic acid standard curve. One unit of PG activity is defined as the amount of enzyme that liberates $1 \mu \mathrm{mol}$ of galacturonic acid per min under the assay conditions. Each data point was an average of triplicate measurements with standard deviation less than $5 \%$. Protein was determined by Lowry method using Bovine serum albumin (BSA) as the standard (Lowry et al. 1951).

\section{Enzyme purification}

Chilled acetone was added slowly up to $30 \%$ saturation with gentle stirring at $4{ }^{\circ} \mathrm{C}$ to the crude enzyme extract. The treated crude enzyme solution was allowed to stand 
overnight in the refrigerator, centrifuged at $10,000 \mathrm{rpm}$ for $15 \mathrm{~min}$. The pellet was discarded and supernatant was saturated up to $60 \%$ with chilled acetone and allowed to stand overnight. The supernatant obtained after centrifugation at $10,000 \mathrm{rpm}$ was again saturated with acetone up to $90 \%$ and was kept undisturbed at $4{ }^{\circ} \mathrm{C}$ overnight. This was centrifuged at $10,000 \mathrm{rpm}$ for $15 \mathrm{~min}$ and the pellet obtained was dissolved in $3 \mathrm{~mL}$ of cold distilled water. The concentrated crude enzyme after subjecting to acetone precipitation was loaded on CM-cellulose column $(6.5 \times 2.0 \mathrm{~cm})$ equilibrated with $10 \mathrm{mM}$ citrate-phosphate buffer $\mathrm{pH}$ 6.0. The adsorbed protein was then washed with two times of bed volume of the same buffer. The protein was eluted stepwise using $10 \mathrm{~mL}$ of $\mathrm{NaCl}(0.1-2.0 \mathrm{M})$ in the citrate-phosphate ( $\mathrm{pH}$ 6.0) buffer at the flow rate of $15 \mathrm{~mL} / \mathrm{h}$. Fractions were collected and analyzed for activity of polygalacturonase and protein. The active fractions were pooled, assayed and stored in deep fridge at $-20^{\circ} \mathrm{C}$. The purity of the enzyme was checked by sodium dodecyl sulfate-polyacrylamide gel electrophoresis (SDS-PAGE) in $10 \%$ acrylamide gel according to Laemmli (1970).

\section{Biochemical characterization of purified polygalacturonase}

The $K_{\mathrm{m}}$ and $k_{\text {cat }}$ values of the purified enzyme were determined by measuring steady-state velocities of the enzyme catalyzed reaction at different concentrations of citrus PGA (0.05-0.6 g\%) in $100 \mathrm{mM}$ citrate-phosphate buffer ( $\mathrm{pH} 4.0)$ at $40{ }^{\circ} \mathrm{C}$ and drawing double reciprocal plot. Calculations were made using linear regression analysis of the data points of the double reciprocal plot. The $\mathrm{pH}$ optimum was determined by measuring steady-state velocity using $0.5 \mathrm{~g} \%$ PGA in the buffered reaction solution using different buffers at $100 \mathrm{mM}$ in the $\mathrm{pH}$ range $1.0-12.0$ and incubating the reaction mixtures at $40{ }^{\circ} \mathrm{C}$ for $30 \mathrm{~min}$. The different buffers used were: hydrochloric acid-potassium chloride ( $\mathrm{pH}$ 1.0-2.0), citrate-phosphate ( $\mathrm{pH} 3.0-7.0)$, sodium phosphate $(\mathrm{pH} 8.0)$, glycine-sodium hydroxide $(\mathrm{pH}$ 9.0-10.0) and sodium phosphate-sodium hydroxide ( $\mathrm{pH} 11.0-12.0)$. The $\mathrm{pH}$ stability of the enzyme was studied by exposing the enzyme to buffers of different $\mathrm{pH}$ for $24 \mathrm{~h}$ at $4{ }^{\circ} \mathrm{C}$. After $24 \mathrm{~h}$, the activities of the enzyme exposed to different $\mathrm{pH}$ were assayed and plotted in the form of relative activity versus $\mathrm{pH}$ at which enzyme was exposed for $24 \mathrm{~h}$.

The optimum temperature for the enzyme activity was determined by assaying activity of the enzyme at different temperatures in the range $10-100{ }^{\circ} \mathrm{C}$ and plotting a graph of the relative activity versus temperature of the reaction solutions. Thermal stability of the enzyme was tested by incubating enzyme aliquots at a particular temperature $\left(10-100{ }^{\circ} \mathrm{C}\right.$ ) for $2 \mathrm{~h}$ and their activities were assayed using the standard assay method.

\section{Effect of metal ions and protein inhibitors}

The effects of metal ions, such as $\mathrm{Ca}^{2+}, \mathrm{Mn}^{2+}, \mathrm{Co}^{2+}$, $\mathrm{Cu}^{2+}, \mathrm{Zn}^{2+}, \mathrm{Hg}^{2+}, \mathrm{K}^{+}, \mathrm{Na}^{+}, \mathrm{Ag}^{+}$and protein inhibitors like potassium permanganate, potassium ferrocyanide and ethylene diamine tetraacetic acid (EDTA) were studied by measuring the steady-state velocity in the reaction solutions containing $1 \mathrm{mM}$ of the metal ions or protein inhibitors and comparing it with the value in the absence of these ions or inhibitors.

\section{Mode of action of purified polygalacturonase}

To decide whether the purified PG is an exo- or endo-PG, a reaction solution containing $0.5 \mathrm{~mL}$ of $1 \%$ PGA in distilled water and $1.4 \mathrm{~mL}$ of $100 \mathrm{mM}$ citrate-phosphate buffer ( $\mathrm{pH}$ 4.0) was added in a test tube. The test tube was incubated in a water bath at $50{ }^{\circ} \mathrm{C}$ and was allowed to stand to maintain the temperature for $20 \mathrm{~min}, 0.5$ unit of the purified enzyme was added. Three- $\mu \mathrm{L}$ aliquots of the reaction solution were withdrawn at 15, 30 and 45 min and spots of these solutions were made on thin layer chromatography (TLC) plate coated with silica gel. Spots of monogalacturonic acid as well as PGA were also made. The TLC plate was kept in a jar containing a solution of butanol, water and acetic acid in the volume ratio 5:3:2 as mobile phase. The TLC plates were air dried, sprayed with $0.2 \%$ (w/v) orcinol in methanol and $10 \%$ sulphuric acid. The plate was air dried and baked in an oven at $80{ }^{\circ} \mathrm{C}$ for 10 min. The spots were photographed.

\section{Clarification of orange juice}

The clarification of fruit juice was studied by reported method of Ishii and Yokotsuka (1972). $50 \mu \mathrm{L}$ of purified enzyme was added to $1 \mathrm{~mL}$ of orange juice $(\mathrm{pH} 4.1)$ and the reaction was incubated at $37^{\circ} \mathrm{C}$ in a water bath. The reaction was stopped by keeping the reaction mixture in boiling water for $5 \mathrm{~min}$. It was centrifuged at $3000 \mathrm{rpm}$ for $5 \mathrm{~min}$. Percentage transmittance was measured at $660 \mathrm{~nm}$ with respect to controls that contained same volume of enzyme added just before keeping the reaction mixture in boiling water.

\section{Results and discussion}

\section{Production of polygalacturonase}

Solid-state fermentation was found to be most effective for polygalacturonase production (Fig. 1). Maximum production was obtained with medium M3 followed by medium M2. Tea extract was found to enhance the enzyme 


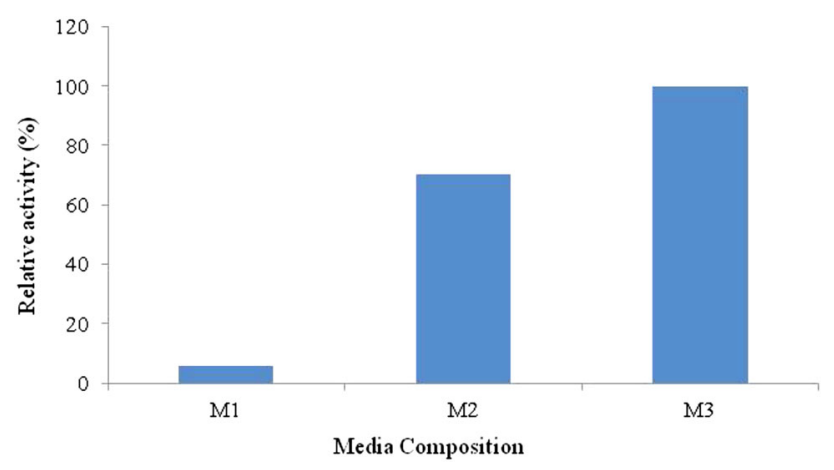

Fig. 1 Effect of media composition on polygalacturonase production by A. niger MTCC 478

production. Previously we have reported pectin lyase production under solid-state fermentation from Fusarium decemcellulare where solid-state media was supplemented with tea extract (Yadav et al. 2014). Negligible polygalacturonase production was obtained under submerged fermentation. There are physiological differences between SSF and SmF, which in turn affect enzyme production in each fermentation system. SSF includes the growth and metabolism of microorganisms in the absence of or nearabsence of any free flowing water. Microbial growth and product formation occur at or near the surface of the solid substrate particle. Such a system, being closer to the natural habitats of microbes, may prove more efficient in producing certain enzymes and metabolites.

\section{Purification of polygalacturonase}

The purification of polygalacturonase from Aspergillus niger MTCC 478 was performed by acetone precipitation and CM-cellulose column chromatography. The purification chart is given in Table 1.

On 5th day, the crude enzyme was harvested and the clear culture filtrate was centrifuged and subjected to acetone precipitation (60-90\% saturation). The precipitate obtained after the acetone precipitation revealed 4.65-fold purification with $4.2 \%$ yield and $10.2 \mathrm{U} / \mathrm{mg}$ specific activity (Table 1). The concentrated crude enzyme after subjecting to acetone precipitation was loaded on CM-cellulose column $(6.5 \times 2.0 \mathrm{~cm})$ equilibrated with $10 \mathrm{mM}$ citratephosphate buffer, $\mathrm{pH}$ 6.0. The adsorbed protein was then washed with two times of bed volume of the same buffer.
The protein was eluted stepwise using $10 \mathrm{~mL}$ of $\mathrm{NaCl}$ (0.1-2.0 M) in the citrate-phosphate (pH 6.0) buffer at the flow rate of $15 \mathrm{~mL} / \mathrm{h}$. Fractions were collected and analyzed for activity of polygalacturonase and protein. Ion-exchange chromatography resulted in 15.28 -fold purification with $1.2 \%$ yield and $33.47 \mathrm{U} / \mathrm{mg}$ of specific activity (Table 1 ). 16-fold purification with $1.9 \%$ yield has been reported for exo-PG from Rhizopus oryzae (Yadav et al. 2012).

The purified PG was confirmed for electrophoretic homogeneity by SDS-PAGE as shown in Fig. 2. The single band corresponding to a relative molecular mass of approximately $124.0 \mathrm{kDa}$ was observed (Fig. 2) which is higher than $106 \mathrm{kDa}$ A. niger polygalacturonase already reported (Kant et al. 2013). Molecular weight of exo-PG from Bacillus sp. was found to be $115 \mathrm{kDa}$ (Kobayashi et al. 2001).

\section{Effect of pH on the activity and stability of PG}

The optimum $\mathrm{pH}$ for the purified polygalacturonase was found to be 4.0 (Fig. 3a) and the enzyme was stable for a wide $\mathrm{pH}$ range, i.e., 3.0-11.0 (Fig. 3b) when exposed to buffers of various $\mathrm{pH}$ for $24 \mathrm{~h}$, indicating its suitability for clarification of fruit juices. Similar pH optimum of 4.0 has been reported for an exo-PG purified from Aspergillus sojae and Paecilomyces variotii (Dogan and Tari 2008; de Lima Damasio et al. 2010). Previous reports show that majority of fungal PGs have their $\mathrm{pH}$ optima in acidic range (Kester and Visser 1990; Polizeli et al. 1991; Niture and Pant 2004; Yadav et al. 2012). However, pH stability range of the enzyme was wider (3.0-11.0) as compared to fungal PGs reported from A. niger (Kant et al. 2013). An endo-PG with stability in alkaline range 7.0-11.0 has recently been reported from A. fumigatus (Anand et al. 2016).

\section{Effect of temperature on the activity and stability of PG}

Optimum temperature for the purified polygalacturonase activity was found to be $50{ }^{\circ} \mathrm{C}$ (Fig. 3c) and the enzyme retained its maximum activity between 10 and $40{ }^{\circ} \mathrm{C}$ for 30 min (Fig. 3d). Similar temperature optimum has been reported for PG from $R$. oryzae (Yadav et al. 2012). Several fungal PGs exhibit temperature optima between 40 and $60{ }^{\circ} \mathrm{C}$ (Devi and Rao 1996; Kaur et al. 2004; Tari et al. 2008; Thakur et al. 2010). PG produced by few thermophilic fungal

Table 1 Purification chart of polygalacturonase from Aspergillus niger MTCC 478

\begin{tabular}{llllll}
\hline Fraction & Total activity $(\mathrm{U})$ & Total protein $(\mathrm{mg})$ & Specific activity (U/mg) & Purification fold & $\%$ Yield \\
\hline Crude & 530 & 242 & 2.19 & - & - \\
Acetone (60-90\%) & 22.6 & 2.2 & 10.2 & 4.65 \\
CM-cellulose & 6.36 & 0.19 & 33.47 & 15.28 \\
\hline
\end{tabular}




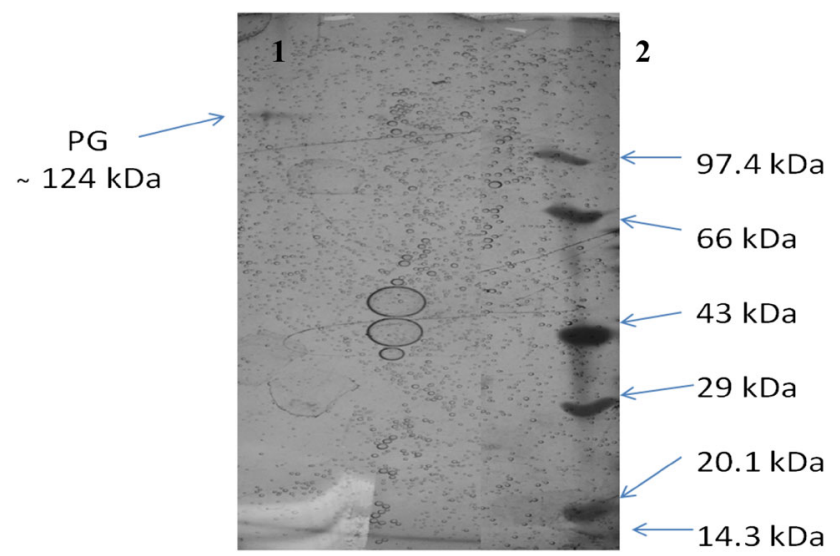

Fig. 2 10\% SDS-PAGE of purified polygalacturonase (PG) from Aspergillus niger MTCC 478. Lane 1 purified PG, Lane 2 protein molecular weight marker

(a)

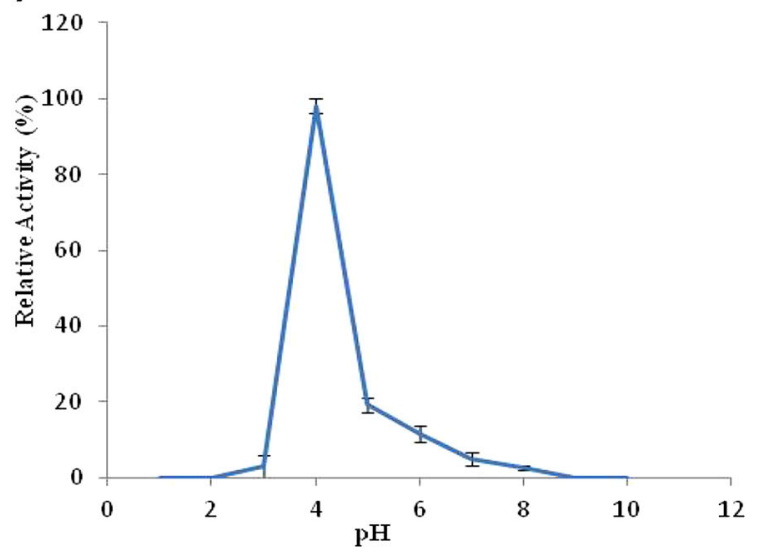

(c)

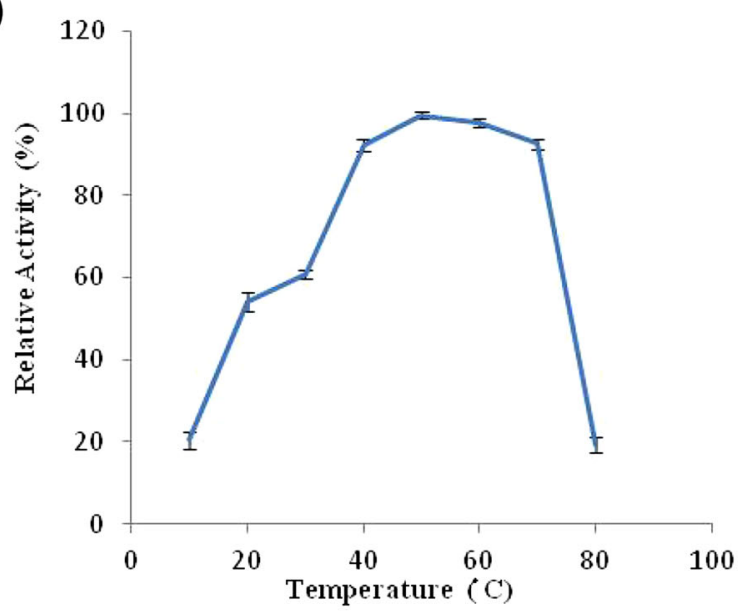

strains like Aspergillus sojae, Paecilomyces variotii and Thermoascus aurantiacus have temperature optima in the range of $60-70{ }^{\circ} \mathrm{C}$ (Dogan and Tari 2008; de Lima Damasio et al. 2010; Martins et al. 2007, 2013). The thermal stability of the purified enzyme is shown in (Fig. 3d) revealing a maximum stability up to $40{ }^{\circ} \mathrm{C}$ and the activity declined sharply above this temperature. Approximately $53 \%$ of the activity was retained at $50{ }^{\circ} \mathrm{C}$.

\section{Kinetic parameters}

The apparent $K_{\mathrm{m}}$ value for degradation of PGA by the purified enzyme was found to be $2.3 \mathrm{mg} / \mathrm{mL}$. The $K_{\mathrm{m}}$ value of $2.4 \mathrm{mg} / \mathrm{mL}$ has been reported for an endo-PG from $A$. niger (Parenicova et al. 1998). An exo-PG from A. tubingensis has $K_{\mathrm{m}}$ value of $3.2 \mathrm{mg} / \mathrm{mL}$ (Kester et al. 1996). The

(b)

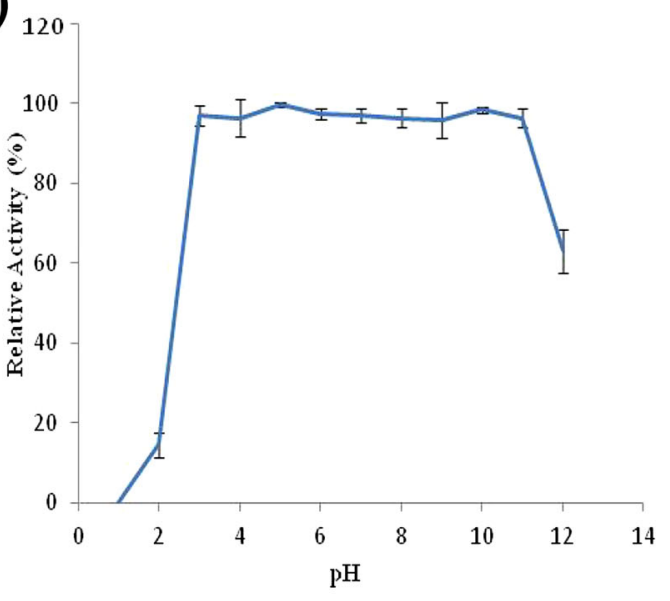

(d)

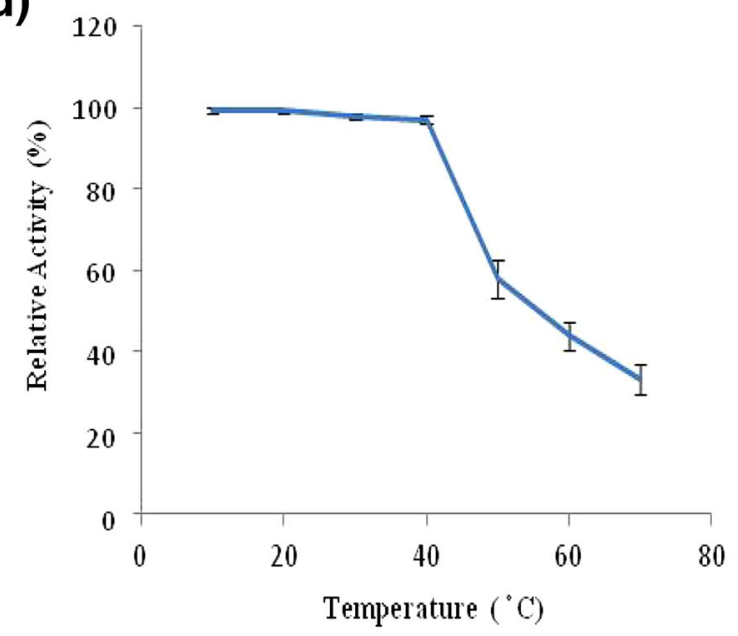

Fig. 3 Effect of $\mathrm{pH}$ and temperature on the activity and stability of purified PG. a pH optima, b pH stability, c temperature optima, d temperature stability 
$K_{\mathrm{m}}$ values of most of the microbial PGs are in the range of 0.1-5.0 (Polizeli et al. 1991; Zhang et al. 1999; Niture et al. 2001; Singh and Rao 2002; Thakur et al. 2010a, b; Yadav et al. 2012; Martins et al. 2013; Chen et al. 2014). An exoPG from the fungus Penicillium frequentans has very low $K_{\mathrm{m}}$ value of 0.059 (Barense et al. 2001) while PG from pathogenic fungus Ustilago maydis revealed comparatively very high $K_{\mathrm{m}}$ of 57.84 (Castruita-Domínguez et al. 2014). The catalytic rate constant $k_{\text {cat }}$ of purified PG was found to be $194 \mathrm{~s}^{-1}$ which is higher than $k_{\text {cat }}$ values of 90 and $70 \mathrm{~s}^{-1}$ for endo-PGs from Aspergillus japonicus and Fusarium moniliforme (Semenova et al. 2003; Niture et al. 2001). Exo-PG from alkaliphilic Bacillus had $k_{\text {cat }}$ value of $22.2 \mathrm{~s}^{-1}$.

\section{Effect of metal ions and protein inhibitors}

The effects of different metal ions and protein inhibitors were assessed using $1 \mathrm{mM}$ concentration of each metal ion in the reaction solution (Table 2). Amongst all metal ions only $\mathrm{Cu}^{2+}$ was found to enhance the PG activity while $\mathrm{Ag}^{+}$ completely inhibited the enzyme activity. Loss of activity may be due to the destabilization of enzyme as a result of loss of surface charge-charge interaction. Enzyme inhibition by $\mathrm{Ca}^{2+}$ may be accounted to its position in Hofmeister series wherein $\mathrm{Ca}^{2+}$ and $\mathrm{Mg}^{2+}$ are more powerful hard cations and strong denaturant. Presence of these metal ions may disturb the ion pairs formed between Asp/Glu and Lys/Arg leading to the destabilization of enzyme (Zeng et al. 2014). It has been reported that activity of an acidic endo-PG from $A$. niger and alkaline endo-PG from A. fumigatus is enhanced by $\mathrm{Cu}^{2+}$ at $1 \mathrm{mM}$ concentration (Zhou et al. 2015; Anand et al. 2016). Metal

Table 2 Effect of metal ions and protein inhibitors on the activity of purified PG

\begin{tabular}{llr}
\hline S. no. & Metal ions $(1.0 \mathrm{mM})$ & Relative activity $(\%)$ \\
\hline & $\mathrm{Control}^{+}$ & 100.0 \\
1 & $\mathrm{Ag}^{+}$ & 14.4 \\
2 & $\mathrm{Ca}^{2+}$ & 34.0 \\
3 & $\mathrm{Co}^{2+}$ & 80.0 \\
4 & $\mathrm{Hg}^{+}$ & 96.0 \\
5 & $\mathrm{~K}^{+}$ & 36.0 \\
6 & $\mathrm{Cu}^{2+}$ & 148.0 \\
7 & $\mathrm{Zn}^{2+}$ & 38.0 \\
8 & $\mathrm{Na}^{+}$ & 97.0 \\
9 & $\mathrm{Mn}^{2+}$ & 95.0 \\
Protein inhibitors & \\
1 & EDTA & 61.0 \\
2 & Potassium permanganate & 98.0 \\
3 & Potassium ferrocyanide & 65.0 \\
\hline
\end{tabular}

ions like $\mathrm{Mn}^{2+}, \mathrm{Hg}^{2+}$ and protein inhibitor $\mathrm{KMnO}_{4}$ had no effect on PG activity. EDTA and $\mathrm{K}_{4}(\mathrm{Fe}) \mathrm{CN}_{6}$ had inhibitory effect on enzyme activity.

\section{Mode of action of purified PG}

To determine the mode of action of the purified PG, TLC experiment was performed (Fig. 4). It is quite obvious that monogalacturonic acid starts appearing on TLC plates from the very beginning and clear spot is visible just after 15 min corresponding to the spot of monogalacturonic acid. This reveals exo-PG nature of the purified PG. Two exo-PGs of molecular weight 82 and $56 \mathrm{kDa}$ from $A$. niger have been reported in the literature (Sakamoto et al. 2002).

\section{Application of purified PG in fruit juice clarification}

In general, microbial pectinases are important group of enzymes with potential applications in various industries like wine industry, paper industry, textile industry and food industry (Garg et al. 2016). Application of purified PG in clarification of fruit juice was studied on orange juice $(\mathrm{pH}$ 4.1) procured from the local market. The clarification of fruit juice was studied by reported method of Ishii and Yokotsuka (1972). Transmittance increased by $27 \%$ with respect to control that contained same volume of enzyme added just before keeping the reaction mixture in boiling water. Transmittance of the treated juice increased because of removal of colloidal and suspended particles in the juice especially pectin. Colloid formation due to the presence of pectin is a major challenge in fruit juice industry, which decreases the commercial value of juices. Pectin present in fruit juices are degraded by pectinases resulting in viscosity reduction and cluster formation. As a result, the juice

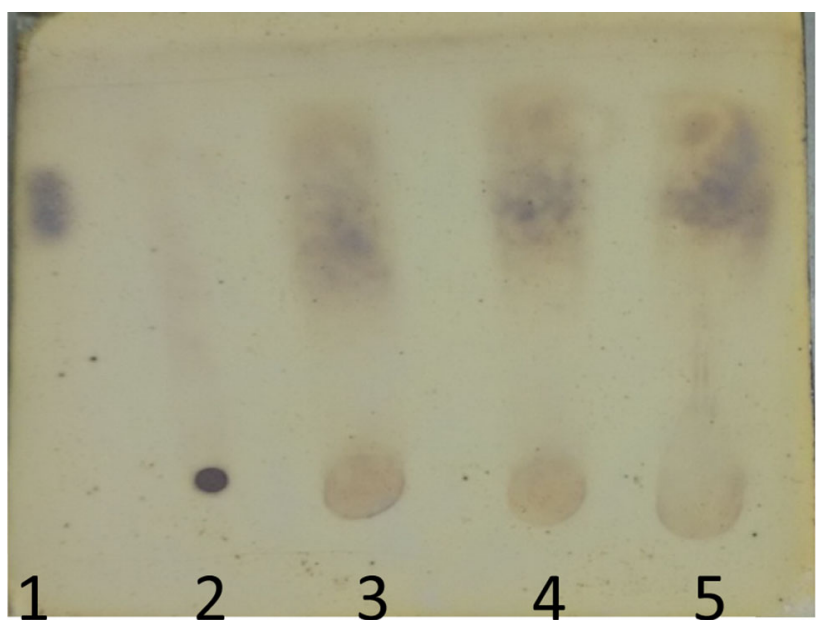

Fig. 4 TLC of purified polygalacturonase (PG) from A. niger MTCC 478. Lane 1 monogalacturonic acid, Lane 2 polygalacturonic acid, Lane 3 reaction after $15 \mathrm{~min}$, Lane 4 reaction after $30 \mathrm{~min}$, Lane 5 reaction after $45 \mathrm{~min}$ 
becomes clear and more concentrated in flavor and color (Liew Abdullah et al. 2007; Kaur et al. 2004). Clarification of fruit juice can be attributed to biochemical nature of the enzyme. The purified enzyme had $\mathrm{pH}$ optima 4.0 and stability in the $\mathrm{pH}$ range 3.0-11.0. Most of the fruit juices are acidic in nature; hence an acidic polygalacturonase with stability in acidic $\mathrm{pH}$ range is a suitable candidate for fruit juice clarification. Several polygalacturonases from Aspergillus carbonarius and Achaetomium sp. Xz8 have been reported to have the capacities to improve the juice yield and clarity (Nakkeeran et al. 2011) and reduce the viscosity of papaya juice ( $\mathrm{Tu}$ et al. 2015). Polygalacturonase produced by $A$. niger using banana peel as a substrate has been used for clarification of banana juice (Barman et al. 2015). Use of polygalacturonases from Neosartorya fisheri in clarification of apple and strawberry juice have also been reported (Pan et al. 2015). An acidic PG from $A$. niger has also been used for the clarification of guava juice (Kant et al. 2013). An acidic endopolygalacturonase from Penicillium oxalicum increased light transmittance of papaya pulp by $29.5 \%$ (Cheng et al. 2016).

\section{Conclusion}

An acidic exo-polygalacturonase from $A$. niger MTCC 478 was produced by solid-state fermentation using cost-effective media comprising of wheat bran and tea extract and was purified simply by acetone precipitation and CM-cellulose column chromatography. A relatively high molecular weight $\mathrm{PG}$ of $124 \mathrm{kDa}$ with $\mathrm{pH}$ and temperature optimum of 4 and $50{ }^{\circ} \mathrm{C}$ was observed. The $k_{\text {cat }}$ and $K_{\mathrm{m}}$ value of purified PG was found to be $194 \mathrm{~s}^{-1}$ and $2.3 \mathrm{mg} /$ $\mathrm{mL}$, respectively, and $\mathrm{Cu}^{2+}$ was found to enhance the PG activity. The potential of purified PG in clarification of orange juice was elucidated owing to its acidic nature.

Acknowledgements GA would like to acknowledge Jawaharlal Nehru Memorial Fund for providing Jawaharlal Nehru Memorial Scholarship for doctoral studies. The financial support by Department of Science and Technology, Government of India, New Delhi, in the form of SERB Young Scientist Fellowship (SB/FT/LS-430/2012) to $\mathrm{S}$. Yadav is also thankfully acknowledged. The authors acknowledge the infrastructural support from the Head, Department of Biotechnology, D.D.U. Gorakhpur University, Gorakhpur.

\section{Compliance with ethical standards}

Conflict of interest Authors have no conflict of interest.

\section{References}

Amin F, Bhatti HN, Bilal M, Asgher M (2017) improvement of activity, thermostability and fruit juice clarification characteristics of fungal exo-polygalacturonase. Int $\mathrm{J}$ Biol Macromol 95:974-984
Anand G, Yadav S, Yadav D (2016) Purification and characterization of polygalacturonase from Aspergillus fumigatus MTCC 2584 and elucidating its application in retting of Crotolaria juncea fiber. 3Biotech 6:201

Barense RI, Chellegatti MASC, Fonseca MJV, Said S (2001) Partial purification and characterization of exopolygalacturonase II and III of Penicillium frequentans. Br J Microbiol 32:327-330

Barman S, Sit N, Badwaik LS, Deka SC (2015) Pectinase production by Aspergillus niger using banana (Musa balbisiana) peel as substrate and its effect on clarification of banana juice. J Food Sci Technol 52:3579-3589

Bird CR, Smith CJ, Ray JA, Moureau P, Bevan MW, Bird AS, Hughes S, Morris PC, Grierson D, Schuch W (1988) The tomato polygalacturonase gene and ripening- specific expression in transgenic plants. Plant Mol Biol 11(5):651-662

Castilho LR, Medronho RA, Alves TLM (2000) Production and extraction of pectinases obtained bu solid state fermentation of agroindustrial residues with Aspergillus niger. Bioresour Technol 71:45-50

Castruita-Domínguez JP, González-Hernández SE, Polaina J, FloresVillavicencio LL, Alvarez-Vargas A, Flores-Martínez A, PonceNoyola P, Leal-Morales CA (2014) Analysis of a polygalacturonase gene of Ustilago maydis and characterization of the encoded enzyme. J Basic Microbiol 54(5):340-349

Chen Y, Sun D, Zhou Y, Liu L, Han W, Zeng B, Wang Z, Zang Z (2014) Cloning, expression and characterization of a novel thermophilic polygalacturonase from Caldicellulosiruptor bescii DSM 6725. Int J Mol Sci 15(4):5717-5729

Cheng Z, Chen D, Lu B, Wei Y, Xian L, Li Y, Luo Z, Huang R (2016) A novel acid-stable endo-polygalacturonase from Penicillium oxalicum CZ1028: purification, characterization and application in the beverage industry. J Microbiol Biotechnol. doi:10.4014/jmb.1511.11045

de Lima Damasio AR, da Silva TM, Maller A, Jorqe JA, Terenzi HF, Polizeli ML (2010) Purification and partial characterization of an exo-polygalacturonase from Paecilomyces variotii liquid cultures. Appl Biochem Biotechnol 160:1496-1507

Devi NA, Rao AGA (1996) Fractionation, purification and preliminary characterization of polygalacturonase produced by Aspergillus carbonarius. Enzyme Microb Tech 18:59-65

Dinu D, Nechifor MT, Stoian G, Costache M, Dinischiotu A (2007) Enzymes with new biochemical properties in the pectinolytic complex produced by Aspergillus niger MIUG 16. J Biotechnol 131:128-137

Dogan N, Tari C (2008) Characterization of three phase partitioned exo-polygalacturonase from Aspergillus sojae with unique properties. Biochem Eng J 39:43-50

Garg G, Singh A, Kaur A, Singh R, Kaur J, Mahajan R (2016) Microbial Pectinases: an ecofriendly tool of nature for industries. 3Biotech 6:47

Hadfield KA, Benett AB (1998) Polygalacturonase: many genes in search of a function. Plant Physiol 117(2):337-343

Ishii S, Yokotsuka T (1972) Clarification of fruit juice by pectin transeliminase. J Agric Food Chem 20:787-791

Jayani RS, Sk S, Gupta R (2010) screening of bacterial strains for polygalacturonase activity: its production by Bacillus sphaericus (MTCC 7542). Enzyme Res. doi:10.4061/2010/306785

Kant S, Vohra A, Gupta R (2013) Purification and physicochemical properties of polygalacturonase from Aspergillus niger MTCC 3323. Prot Exp Purif 87:11-16

Kashyap DR, Vohra PK, Chopra S, Tewari R (2001) Applications of Pectinases in commercial sector: a review. Biores Technol 77:215-227

Kaur G, Kumar S, Satyanarayana T (2004) Production, characterization and application of a thermostable polygalacturonase of a thermophilic molud Sporotrichum thermophile. Apinis Bioresour Technol 94:239-243

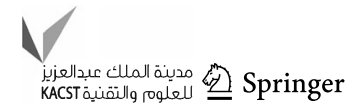


Kester HC, Visser J (1990) Purification and characterization of polygalacturonases produced by the hyphal fungus Aspergillus niger. Biotechnol Appl Biochem 12(2):150-160

Kester HCM, Kusters-Van Someren MA, Muller Y, Visser J (1996) Primary structure and characterization of an exopolygalacturonase from Aspergillus tubingensis. Eur J Biochem 240:238-246

Kobayashi T, Higaki N, Suzumatsu A, Sawada K, Hagihara H, Kawai S, Ito S (2001) Purification and properties of a high- molecularweight, exo-polygalacturonase from a strain of Bacillus. Enzyme Microb Technol 29:70-75

Laemmli UK (1970) Cleavage of structural proteins during the assembly of the head of bacteriophage T4. Nature 227(5259):680-685

Lara-Marquez A, Zavela-Paramo MG, Lopez-Romero E, Horacio CC (2011) Biotechnological potential of pectinolytic complexes of fungi. Biotechnol Lett 33:859-868

Liew Abdullah AG, Sulaiman NM, Aroua MK, Megat Mohd Noor MJ (2007) Response surface optimization of conditions for clarification of carambola fruit juice using a commercial enzyme. J Food Eng 81:65-71

Lowry OH, Rose Brough NJ, Farr AL, Randall RJ (1951) Protein measurement with Folin phenol reagent. J Biol Chem 193:265-275

Martins ES, Leite RSR, Silva R, Gomes E (2013) Purification and properties of polygalacturonase produced by thermophilic fungus Thermoascus aurantiacus CBMAI-756 on solid-state fermentation. Enzyme Res. doi:10.1155/2013/438645

Martins ES, Silva D, Leite RSR, Gomes E (2007) Production and characterization of polygalacturonase produced by thermophilic Thermoascus aurantiacus CBMAI-756 in submerged fermentation. A Van Leeuw 91:291-299

Miller GL (1959) Use of dinitrosalicylic acid reagent for determination of reducing sugar. Anal Chem 31(3):426-428

Mohnen D (2008) Pectin structure and biosynthesis. Curr Opin Plant Biol 11:266-277

Molina SMG, Pelissari FA, Vitorello CBM (2001) Screening and genetic improvement of pectinolytic fungi for degumming of textile fibres. Br J Microbiol 32:320-326

Mrudula S, Anitharaj R (2011) Pectinase production in solid-state fermentation by Aspergillus niger using orange peel as substrate. Glob J Biotechnol Biochem 6:64-71

Nakkeeran E, Umesh-Kumar S, Subramanian R (2011) Aspergillus carbonarius polygalacturonases purified by integrated membrane process and affinity precipitation for apple juice production. Biores Technol 102:3293-3297

Niture SK, Pant A (2004) Purification and biochemical characterization of polygalacturonase II produced in semi-solid medium by a strain of Fusariummoniliforme. Microbiol Res 159:305-314

Niture SK, Pant A, Kumar AR (2001) Active site characterization of the single endo-polygalacturonase produced by Fusarium moniliforme NCIM 1276. Eur J Biochem 268:832-840

Ortega LM, Kikot GE, Rojas NL, Lopez LM, Astoreca AL, Alconada TM (2014) Production, characterization, and identification using proteomic tools of a polygalacturonase from Fusarium graminearum. J Basic Microbiol 54:S170-S177

Oszmianski J, Wojdylo A, Kolniak J (2009) Effect of enzymatic mash treatment and storage on phenolic composition, antioxidant activity, and turbidity of cloudy apple juice. J Agric Food Chem 57:7078-7085

Pan X, Li K, Ma R, Shi P, Huang H, Yang P, Meng K, Yao B (2015) Biochemical characterization of three distinct polygalacturonases from Neosartorya fischeri P1. Food Chem 188:569-575

Parenicova L, Benen JA, Kester HC, Visser J (1998) pgaE encodes a fourth member of the endopolygalacturonase gene family from Aspergillus niger. Eur J Biochem 251:72-80

Pedrolli DB, Carmona EC (2009) Pectin lyase from Aspergillus giganteus: comparative study of productivity of submerged fermentation on citrus pectin and orange waste. Prikl Biokhim Mikrobiol 45:677-683

Perrone G, Mule G, Susca A, Battilani P, Pietri A, Logrieco A (2006) Ochratoxin A production and amplified fragment length polymorphism analysis of Aspergillus carbonarius, Aspergillus tubingensis, and Aspergillus niger strains isolated from grapes in Italy. Appl Environ Microbiol 72:680-685

Polizeli MLTM, Jorge JA, Terenzi HF (1991) Pectinase production by Neurospora crassa: purification and biochemical characterization of extracellular polygalacturonase activity. J Gen Microbiol 137:1815-1823

Sakamoto T, Bonnin E, Quemener B, Thibault JF (2002) Purification and characterization of two exo-polygalacturonases from Aspergillus niger able to degrade xylogalacturonan and acetylated homogalacturonan. Biochim Biophys Acta 1572(1):10-18

Semenova MV, Grishutin SG, Gusakov AV, Okunev ON, Sinitsin AP (2003) Isolation and properties of Pectinases from the fungus Aspergillus japonicas. Biochem (Moscow) 68:559-569

Silva D, Martins ES, Silva R, Gomes E (2002) Pectinase production by Penicillium viridicatum RFC3 by solid state fermentation using agricultural wastes and agro-industrial byproducts. $\mathrm{Br} \mathrm{J}$ Microbiol 33:318-324

Singh SA, Rao AGA (2002) A simple fractionation protocol for, and a comprehensive study of the molecular properties of, two major endopolygalacturonases from Aspergillus niger. Biotechnol Appl Biochem 35(2):115-123

Takao M, Nakaniwa T, Yoshikawa K, Terashita T, Sakai T (2000) Purification and characterization of thermostable pectate lyase with protopectinase activity from thermophilic Bacillus sp. TS 47. Biosci Biotechnol Biochem 64:2360-2367

Tari C, Dogan N, Gogus S (2008) Biochemical and thermal characterization of crude exo- polygalacturonase from Aspergillus sojae. Food Chem 111:824-829

Tariq A, Latif Z (2012) Isolation and biochemical characterization of bacterial isolates producing different levels of polygalacturonase from various sources. Afr J Microbiol Res 6(45):7259-7264

Thakur A, Pahwa R, Singh S, Gupta R (2010) Production, purification, and characterization of polygalacturonase from Mucor circinelloides ITCC 6025. Enzyme Res. doi:10.4061/2010/170549

Tu T, Luo H, Meng K, Cheng Y, Ma R, Shi P, Huang H, Bai Y, Wang Y, Zhang L, Yao B (2015) Improvement in thermostability of an Achaetomium sp. Strain Xz8 endopolygalacturonase via the optimization of charge-charge interactions. Appl Environ Micrbiol 81(19):6938-6944

Yadav S, Anand G, Dubey AK, Yadav D (2012) Purification and characterization of an exo-polygalacturonase secreted by Rhizopus oryzae MTCC1987 and its role in retting of Crotolaria juncea fibre. Biologia 67(6):1069-1074

Yadav S, Dubey AK, Anand G, Kumar R, Yadav D (2014) Purification and biochemical characterization of an alkaline pectin lyase from Fusarium decemcellulare MTCC 2079 suitable for Crotolaria juncea fiber retting. J Basic Microbiol 54:S161-S169

Yadav S, Shastri NV (2007) Purification and properties of an extracellular pectin lyase produced by the strain of Penicillium oxalicum in solid-state fermentation. Indian J Biochem Biophys 44:247-251

Yadav PK, Singh VK, Yadav S, Yadav KDS, Yadav D (2009) In silico analysis of pectin lyase and pectinase sequences. Biochem (Moscow) 74(9):1049-1055

Zeng J, Gao X, Dal Z, Tang B, Tang X-F (2014) Effects of metal ions on stability and activity of hyperthermophilic pyrrolysine and further stabilization of this enzyme by modification of a $\mathrm{Ca}^{2+}$. binding site. Appl Environ Microbiol 80:2763-2772

Zhang J, Bruton BD, Biles CL (1999) Fusarium solani endopolygalacturonase from decayed muskmelon fruit: purification and characterization. Physiol Mol Plant Pathol 54:171-186 